Government under financial pressure), the need for an advanced trainer, which is what the Jaguar is, is very far from obvious.

Of course, like most aircraft these days, the Jaguar is expected to do more than simply train pilots to fly at Mach $\mathbf{1 \cdot 7 .}$. The aircraft has five roles: as an advanced trainer for the French and British air forces, as a tactical support aircraft by both air forces, and as a tactical aircraft for the French Navy. As a tactical aircraft, Jaguar can carry a variety of systems-air to air

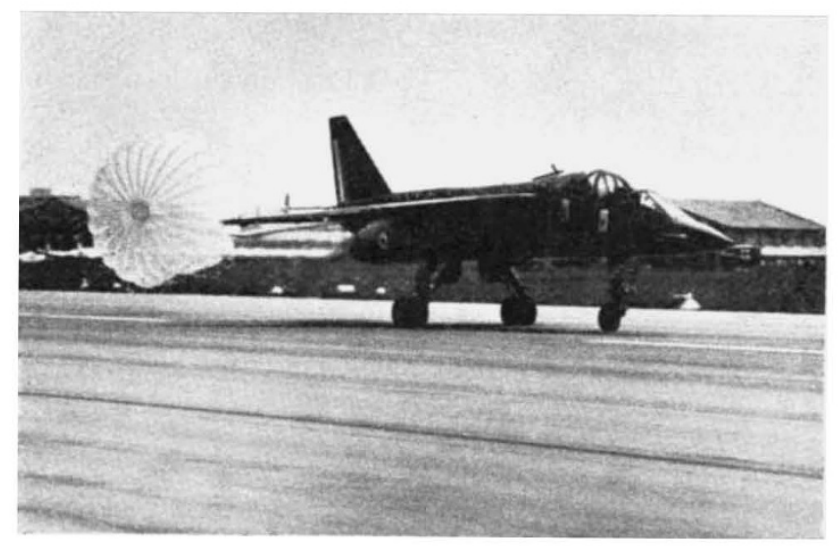

missiles, 1,000 lb bombs, rocket launchers and Martel missiles, though not all at once. The British Ministry of Defence originally stated that the Jaguar would be used to enable Phantoms to be released to replace obsolete Lightnings. In this sense, it is a secondary strike system, cheap to buy, easy to fly, with the capacity to take off from short, ill-prepared runways and with a good range. It is small, about the same size as the Hawker Hunter, has a radius of action of 320 nautical miles, and can be flown for 2,430 nautical miles if external fuel tanks are fitted. The aircraft has two engines, built jointly by Rolls-Royce and Turbomeca, and called the RB 172 T260 Adour.

So far, this sounds like a blueprint for a replacement for the Hawker Hunter in air forces like those of Jordan. And it is clear that the makers of the aircraft are hoping for substantial export orders-they hope 1,000 Jaguars can be sold. If they are not, the project can hardly be justified. Although the aireraft has some room for development, it is never likely to amount to an effective substitute for the cancelled variable geometry aircraft. $£ 124$ million is a lot to pay for a squadron or two of relatively unsophisticated aeroplanes-even in the training function, the Jaguar will not be the complete answer. The Ministry of Defence also intends to produce a training version of the Harrier, another small aircraft which at least has vertical take-off to recommend it. But there are signs that an export market exists - a fairly well substantiated story suggests that Japan is in the market for the Adour engine, to power its own training aircraft, the TX. This will please Rolls-Royce, although the British Aircraft Corporation would doubtless prefer to sell the entire aircraft.

\section{Reflexions on Todd}

Enthusiasm tinged with fear seems to be the general reaction to the Todd report on medical education (see
Nature, 218, 121 ; 1968). Enthusiasm for a majority of the proposals is dampened by the fear that the report will be pigeonholed and no action taken. Developments now in the pipeline but not in line with the report would therefore be dropped with nothing else put in their place. As it is, changes like a reorganization of curricula have been hanging around waiting for the recommendations. Building plans in various stages of completion are also affected.

Expansion of medical training is obviously necessary. The recommendations for the form that the training should take seem to have received widespread approval. Pre-clinical teachers are welcoming the idea of a medical degree, although the cost of providing enough laboratory accommodation is likely to be a drawback. Vocational training for general practitioners as described in the report includes much that has already been called for by the College of General Practitioners. Although some critics say that, with the current shortage of general practitioners, this is no moment to raise the standards, there is a feeling that unless something is done in this direction people will not be attracted into general practice at all and the shortage will become more serious. Recommendations for reorganization of the curriculum are welcomed, although there are doubts about the availability of staff and money which would be necessary. Contributions by the students would help this problem, and it has been suggested that this would be a good moment to review the whole question of student financing, both in medicine and other subjects.

A large section of the report deals with the hospitals and medical schools in London. It has been recognized for some time that some sort of rationalization is necessary, and the proposed links of teaching hospitals with university colleges are welcomed. On the other hand, there is a feeling that the postgraduate hospitals might lose their identity if grafted on to the new double undergraduate hospitals. The report suggests rather than makes definite recommendations about how the various institutes and postgraduate hospitals might join up, but it seems likely that even the suggestions will not be too kindly received. The Institute of Neurology and the National Hospital in Queen Square, for example, are already involved with plans for rebuilding on the present site, and they see no reason to move to join the Guy's/King's College group when they are so close to various libraries and particularly to University College, where basic neurological research is carried out. It has been murmured that the commission, in its attempts at rationalization, ended up playing jigsaws, fitting in the postgraduate hospitals to make a tidy picture rather than for positive reasons. And the Hammersmith hospital, which has its own particular brand of postgraduate school staffed entirely by full-time university staff, has been left with no undergraduate link, although such links are an important feature of the report.

\section{IBP General Assembly}

The International Biological Programme (IBP) is very nearly a year into the active phase of its five-year lifetime, but already there are worries about what is to happen to uncompleted projects when the programme ends in 1972. There are likely to be quite a number. Most of the American and Soviet IBP projects, for 
instance, have not yet started; the Soviet Union has only just published its national programme. This was one of the policy themes under discussion at the annual IBP General Assembly and meeting of the Special Committee for IBP (SCIBP) held this April at Varna on the Black Sea coast of Bulgaria. It is now "as clear as a bell" according to the IBP Scientific Director, Dr E. B. Worthington, that much IBP work cannot be finished by the end of 1972 . There must be a mechanism for checking progress and for continuing the promising work after that time. Even more important is a mechanism for closing down the unpromising activity, but this is now in hand. Plans are being made for assessing the work of each of the seven sections into which IBP research is organized and for evaluating themes within the sections. Before the conference an index to IBP projects was abstracted by the central office from the thirty-odd national programmes so far available. 1,400 projects are identified in this document. They are classified under subject, section and the scientist responsible for them.

The Eastern Europe venue for the meeting proved encouraging not only for Russian participation but also to scientists of the other socialist countries, who have lacked not enthusiasm but mobility in previous years. A curious situation emerged at the meeting. Although ecological science appropriate to IBP is at a high level in the Eastern European countries, there is little co-operation between the different national workers. It has needed an IBP to bring them together. For instance, on the Lower Danube the com. mercially valuable fisheries and vegetation are extensively studied by the scientists of Rumania and Bulgaria for which the river forms a common border, but up till now they have not shared their results or co-ordinated their activities.

Soviet authorities have paid lip service to IBP, but they have not played much part in the international planning and preparations. Things are now on a much better footing. Quite a large Soviet contingent was present at Varna. Their long awaited programme was available-well produced and in English. The newly appointed secretary of the national committee proved to be a professor of zoology at Leningrad University of great energy and with an excellent command of English. At the meeting a very distinguished Soviet limnologist, Professor Winberg, accepted the vacant post of convener for the Freshwater Productivity section (PF) from the retiring American. Two major international scientific conferences on IBP themes are to be held in the Soviet Union this year; one on plant root systems at the end of the summer and the other, on the place of bacteria in freshwater productivity, in the winter. Russian scientists have made both subjects peculiarly their own.

Improved relations in another important sector are reported from the conference. FAO (the UN Food and Agriculture Organization) is showing a much changed attitude towards IBP since the appointment of the new Director-General, Dr A. H. Boerma. Lengthy discussions held recently between IBP Central Office staff and all FAO departments have led to the intention to make much departmental work available to the programme.

Shortage of funds continue to hamstring IBP activities centrally as well as at the national programme level. The meeting passed a resolution to be forwarded to the parent body, ICSU, to raise the national subscriptions for the coming year. These are on a three-tier basis, and on the new tariff the highest subscription will be $\$ 25,000$ instead of $\$ 10,000$ and the lowest $\$ 250$ instead of $\$ 100$. But this will not help the running expenses for this year.

\section{New Council for Nature}

THe argument which has sprung up over the control of the Council for Nature concerns the new constitution which was adopted at the extraordinary general meeting on April 20. Since its foundation in 1959, to co-ordinate at a national level the views and opinions of unofficial bodies concerned with conservation and natural history, the Council for Nature has had an executive committee elected from among its member bodies, of which there are now 450 . Of these, the museums and universities had one representative each, and there are several representatives from national and local natural history societies and conservation organizations. There are also eight places filled by experts in various aspects of natural history, nominated by the executive committee itself to ensure that important sections of nature were not overlooked in the council's activities. At a general meeting in 1967, it was decided that these eight members should be nominated by national societies and not appointed by the executive committee.

Under the new constitution, the executive committee is replaced by a council with members appointed by other bodies. Four members will be appointed by the Royal Society for the Protection of Birds and four by the Society for the Promotion of Nature Reserves and its County Naturalists' Trusts Committee. A Natural History Societies' Committee, to be set up by the council and to consist of representatives of national, regional and local affiliated bodies particularly concerned with natural history, will also appoint four members to the council. The Fauna Preservation Society will appoint two members and the rest will be appointed one each by nine other organizations including the Scottish Wildlife Trust, the Field Studies Council, the Linnean Society, the Botanical Society of the British Isles and the Museums Association.

These changes are regarded by the Council for Nature as a necessary step towards closer co-ordination with other voluntary bodies concerned with conservation. The old executive committee, when recommending the changes, advised that "to avoid overlapping of function, it is advisable that the Council for Nature should neither appear to be, nor act like, a society in its own right".

The work of the council will continue to involve national co-ordination and promotion of ideas and activities concerned with natural history and conservation. The latest report of the council, entitled Working for Nature, records the council's role in promoting in Parliament bills concerned with the countryside, the protection of wild plants and the conservation of seals. The Conscrvation Corps, with about 13,500 available volunteers, has continued its various field activities such as laying hedges, making nature trails and generally helping to manage the countryside. The local member bodies have continued to receive information and advice from the council, which admits 